\title{
Ethnomedicinal uses of indigenous plant species in Mogalakwena Municipality of Waterberg District, Limpopo Province South Africa
}

\section{L.P. Maema*, S.M. Mahlo and M.J. Potgieter}

Department of Biodiversity, School of Molecular and Life Sciences, University of Limpopo, Private Bag X1106, Sovenga 0727, South Africa.

\section{ABSTRACT}

Various indigenous cultures in the Limpopo Province of South Africa are transitioning from a traditional lifestyle to a westernised one. This leads to a loss of cultural identity and knowledge. Consequently, an ethnobotanical survey was conducted to investigate the medicinal uses of indigenous plants in the Mogalakwena Local Municipality of the Waterberg District in Limpopo Province, South Africa, an area experiencing rapid transition to a western lifestyle. The study interviewed 30 traditional healers via a semi-structured questionnaire. Thirty five indigenous plant species were documented to be used in the treatment of 37 ailments. These species are distributed among 22 families, of which Asteraceae (5 species), Fabaceae (4 species) and Hyacinthaceae (3 species) are the most prominent. The remaining families are represented by either a single or two species. Bark and roots accounted for $50 \%$ of the material used, followed by leaves (12\%) and tuber ( $8 \%)$, amongst other. Preparation of remedies was mainly through decoctions $(40 \%)$, followed by infusions (33.3\%), paste (8.3\%), and fumes through burning (6.7\%). The high percentage of bark and roots use is an area of concern. Furthermore this study found many instances of unsustainable harvesting techniques. These issues need immediate attention for the long term conservation of a number of threatened species identified in this study.
Keywords:

Bapedi traditional health practitioners, Mogalakwena Local Municipality, ethnomedicinal survey

*Correspondence to Author: Lesibana Petrus Maema

Department of Biodiversity, School of Molecular and Life Sciences, University of Limpopo, Private Bag X1106, Sovenga 0727, South Africa. Email: plesibana@gmail.com

\section{SciencePublisher} eSciPub LLC, Houston, TX USA. Website: http://escipub.com/ 


\section{INTRODUCTION}

South Africa has a long history of traditional medicinal usage and is imbedded with unique and diverse indigenous cultures (van Vuuren, 2008), which produced a rich heritage of traditional knowledge on the uses of medicinal plants (Iwu, 2014). In this regard, Dahlberg and Trygger (2009) view indigenous knowledge as local, unique and traditional, crafted around specific conditions by a community to a particular area. This localised indigenous knowledge plays a vital role in the treatment of a variety of ailments by traditional health practitioners (Mathibela, 2012).

Traditional medicine plays an important role in the primary health care of South Africa (Truter, 2007). Here traditional health practitioners hold a significant repository of information about medicinal plants and their application in primary health care. In South Africa, approximately 200 000 traditional health practitioners use herbal medicine for treatment of various ailments, servicing about $80 \%$ of the population in primary health care (Lewu and Afolayan, 2009). It is estimated that over one-third of the world's population lacks regular access to modern medicine and therefore traditional medicine systems is sometimes seen as the only affordable source of health care, especially for those in impoverished rural areas (Zhang, 2004). Williams et al. (2000) noted that the utilization of various plant species by traditional health practitioners is influenced by the diversity and geographical distribution of medicinal plants.

South Africa is endowed with a rich plant diversity, hosting about more than 30000 higher plant species (Van Wyk \& Smith, 2001), which is about $6 \%$ of the planet's plant species (Driver et al., 2012). South Africa is further recognised as one of only 17 megadiverse countries. Driver et al. (2012) further noted that more than 2000 plant species is used medicinally in South Africa. Irrespective of high plant diversity, Van Wyk (2008) showed that medicinal plants that are used in Africa are not well described and studied, and the information remains entrenched in local communities.

African indigenous knowledge systems are predominantly oral and not written-based, and therefore susceptible to loss and change over time (Van Wyk et al., 2009). Weitz and Thring (2005) stated that from a cultural point of view it is important to document this knowledge for use by future generations. Therefore, the present study aimed to document indigenous plant species that are used to treat various diseases in human and to identify their conservation status in the Mogalakwena Municipality of the Waterberg District, Limpopo Province, South Africa.

\section{MATERIALS AND METHODS}

\section{Study area and demographics}

The study was conducted in the Mogalakwena Municipality of the Waterberg District, Limpopo Province, South Africa (Figure 1). Geographically Mogalakwena Municipality lies between $23^{\circ} 10^{\prime}-24^{\circ} 20^{\prime} S$ and $28^{\circ} 10^{\prime}-29^{\circ} 10^{\prime} E$ (BGIS.Sanbi.org). The Mogalakwena Municipality covers an area of $6166 \mathrm{~km}^{2}$, hosting 614139 people, with black Africans the dominant group, comprising $90 \%$ of the population. Poverty due to high levels of unemployment still remains a major challenge in Mogalakwena Municipality. Consequently the majority of the people resides in villages, and relies primarily on agricultural and subsistence farming activities to meet their livelihood needs (StatsSA, 2012).

\section{Ethnobotanical survey}

Data was collected from June 2015 to November 2015 in 15 local villages within the study area. Two Bapedi (the dominant cultural group) traditional health practitioners were selected via the convenient sampling method, resulting in 16 females and 14 male healers been interviewed. Our respondents were in an age range of between 25 to 70 years. Data was collected using a semi-structured questionnaire using the face-toface interview technique as described in similar studies (Akaydin, 2013; Seid and Aydagnehum, 2013), supplemented with guided field tours with traditional health practitioners . Information such as vernacular name, source of plants collection, plant part(s) used, ailments treated, as well as preparation methods and dosage were documented.

\section{Plant collection and identification}

Voucher specimens, as pointed out by accompa- 
nied traditional health practitioners, were collected from both home gardens and natural communal areas. Plant species were initially identified by their vernacular names. Later taxonomic identification was done by a trained taxonomist at the Larry Leach Herbarium (UNIN) of the University of Limpopo.

\section{Statistical analysis}

The data was captured in Microsoft Excel 2010. A descriptive statistic procedure like percentage and frequency distribution were employed for data analysis.

\section{Ethical considerations}

A permit was requested and obtained from various traditional councils within the Mogalakwena Municipality for conducting research within their area of jurisdiction, and to meet with traditional health practitioners in order to request them to participate in the study. Each traditional healer was requested to sign a consent form as approved by the University of Limpopo. As such all ethics related to people's privacy, confidentiality, and anonymity, were observed, adhered to and respected. Participants in this study were voluntary, participated freely and anonymously. The sources of primary and secondary data and information are acknowledged.

\section{RESULTS}

\section{Species diversity}

The current study documented 35 indigenous plant species belonging to, 33 genera and 23 families. The Asteraceae (Compositae) are represented by 5 plant species, Fabaceae by 4 plant species, followed by the Hyacinthaceae (3 plant species). The families Anacardiaceae, Combretaceae, and Euphorbiaceae are presented by two plant species each, while the remaining families contained one plant species each.

A very similar picture comes to light regarding genera diversity. Most genera are represented by one or two species. However, the most prominent genera occur in the Asteraceae (5 genera), Fabaceae (4 genera) and Hyacinthaceae (3 genera) (Table 1).
Trees are the most dominant (40\%), followed by herbaceous plants (20\%), geophytes and shrubs constituted $11.4 \%$ each, whereas succulent, creepers, climber contributed 8.6\%, 5.7\%, 2.9\% respectively.

The most frequently used plant species is Drimia elata, followed by Ziziphus mucronata, Eucomis palladiflora, Geigeria aspera, Adenia glauca, Hypoxis hemerocallidea, Elaedendron transvalense, and Dicoma anomala (Figure 2).

\section{Plant parts used}

This study found that 9 different plant parts are used to prepare remedies. The most used plant part was bark and roots used in $25 \%$ of documented cases, followed by roots leaves (16\%), tuber $(8 \%)$. Stems and bulbs as well as using the entire plant were recorded $6 \%$ of the time. It was further noticed that fruits and rhizomes were only used in $2 \%$ and $4 \%$ respectively of the documented cases (Figure 3).

\section{Ailments treated}

The study recorded 37 different ailments that are being treated through traditional medicine. These treatments ranged from simple headaches, earaches and skin rush to complicated treatments involving HIVIAIDS and Tuberculosis (Table 1). The most frequently treated ailments are; respiratory infections $(27.4 \%)$, followed by general diseases $(23.7 \%)$ such as immunization, fever, blood cleansing, hypertension, to more specialised treatment for liver and kidney failure, gastro-intestinal problems (17.8\%), dermatological $(12.6 \%)$ and gynaecological ailments (6.7\%).

Of all ailments treated, coughing was frequently mentioned ailment treated in the study area. The high frequency of treated ailment can be linked to the number of available medicinal plants. For instance, seven plants species are used to treat cough and this provide several options when other plant species are available. Another ailment that is highly treated is blood cleaning, in which six different species can be used as alternatives (Table 1). It is also worth noting that single plant species can be utilized to treat several ailments depending on plant part used as well as prepa- 


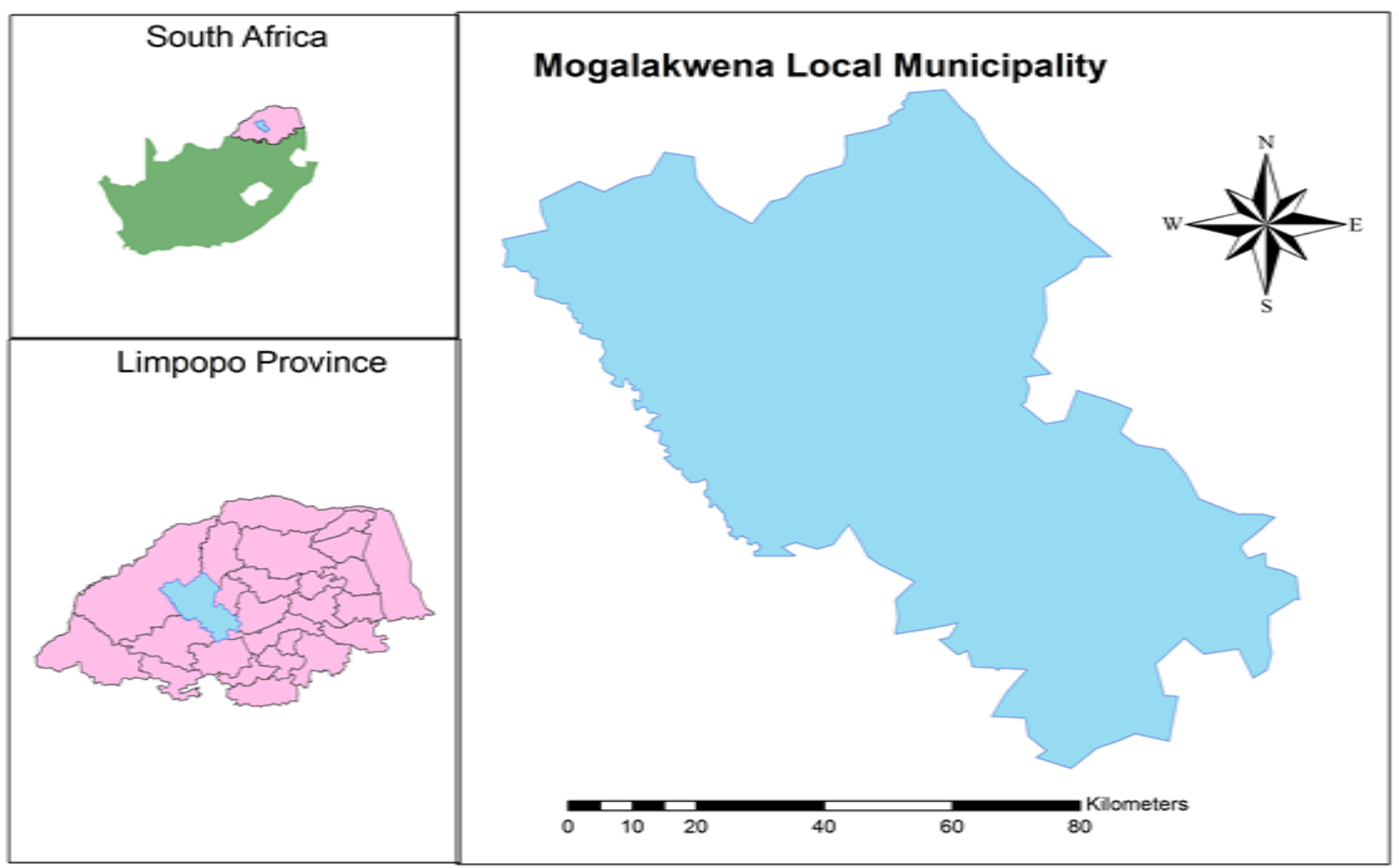

Figure 1. Study area: Mogalakwena Municipality.

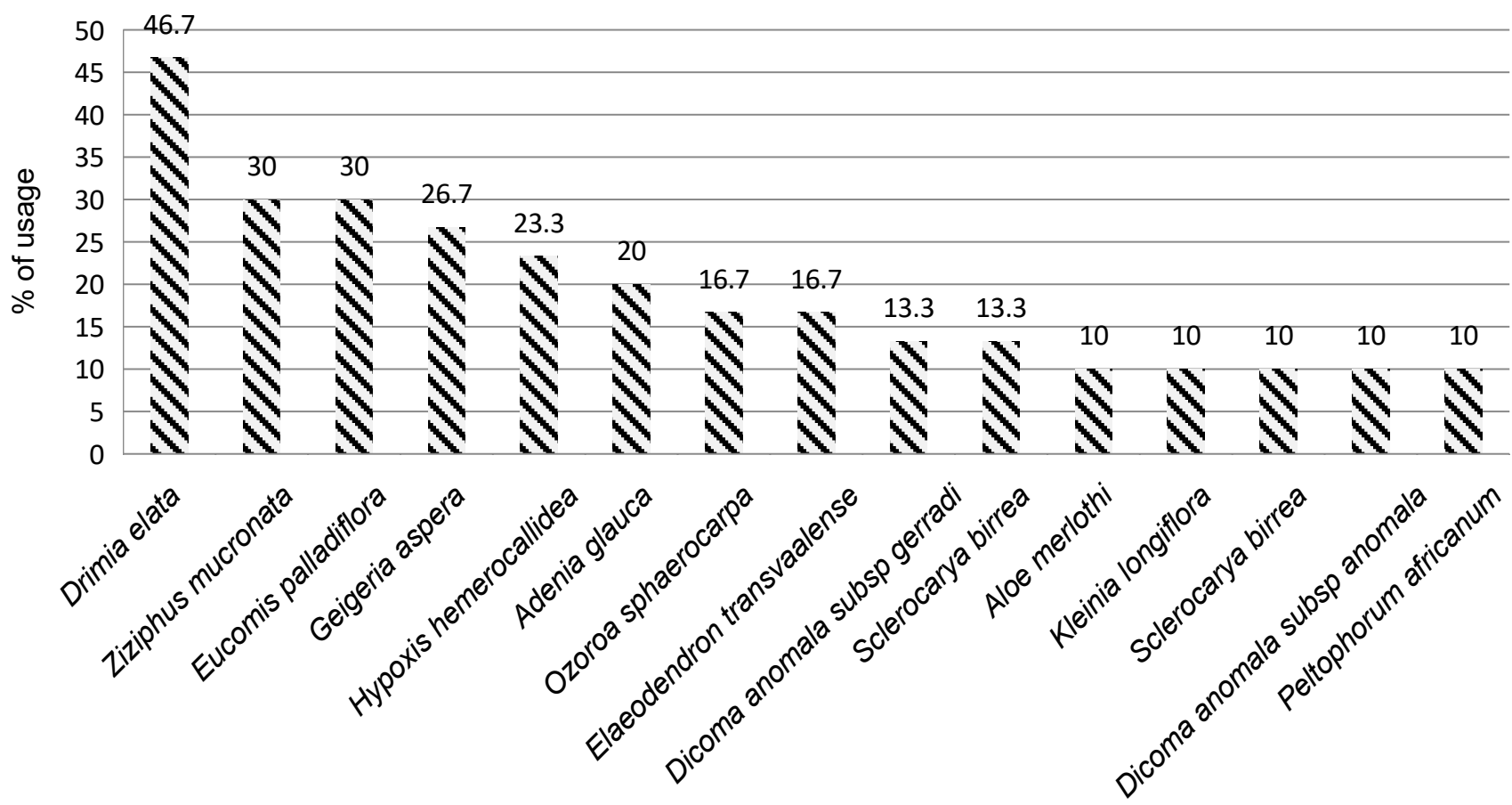

Figure 2: Frequency of used plant species. 
ration method. It is evidenced that $45 \%$ of documented plants are used to treat single ailments, $35 \%$ can treat two ailments whereas $7.5 \%$ can treat 3 different ailments. Furthermore, five species namely: Drimia elata, Geigeria aspera, $\mathrm{Hy}$ poxis hemerocallidea and Ziziphus mucronata are used to treat more than three disease ailments (Figure 4).

\section{Preparation of remedy}

Method of preparation is mainly through decoction $(40 \%)$, followed by infusions (33.3\%), paste $(8.3 \%)$, burning $(6.7 \%)$, and powder $(5 \%)$, whereas chewing and squeezing of the juice contributed $1.7 \%$ each.

About $87 \%$ of remedies was prepared from only one species, $10 \%$ through a mixture of two different species, and in 3\% of cases material from three plant species were combined to prepare a remedy. For instance, two species are involved the preparation of a decoction used for the immunization of infants roots. Here roots of Asparagus sauveolens and stem of Adenia glauca are used. In another example, squeezed juice of $D i$ coma anomala subsp gerraddi plants is mixed with powdered bark of Ozoroa sphaerocarpa to treat Tuberculosis. In another classic example of mixing two species, Dicerocaryum eriocarpum is mixed with Bidens pilosa to clean the womb after birth. A decoction of both Ozoroa sphaerocarpa and Solanum panduriforme roots are used to clear nasal blockage. In a case of mixing three species gum and roots of Ximenia caffra and roots of Ziziphus mucronata and Datura stromanium are used to treat uncontrolled menstruation and infertility in women. It is important to highlight that exotic plants such as Bidens pilosa and Datura stromanium are also combined with indigenous plants for preparation of remedy.

\section{Mode of administration}

Administration depends on the preparation methods and ailments treated. This study recorded oral $(71.7 \%)$ as the most used administration mode, followed by topical applications (11.7\%), bathing $(6.7 \%)$, ear drop and sublingual $(3.3 \%$ each), whereas gargling and inhaling smoke contributed $1.7 \%$ each.

\section{Dosage}

Prescriptions vary considerably with traditional health practitioners. In the case of oral administrations, the general dosage is either half cup or full tin cup $(300 \mathrm{ml})$, taken twice or thrice a day after meals. Some infusions require a mixture of half powdered tablespoon or full teaspoon in $300 \mathrm{ml}$ cup. It was further noticed that a finger pinch of powdered plant part is often mixed with a teaspoon of cooking oil. For instance, a pinch of dried and powdered tuber of Dicoma anomala subsp anomala is mixed with cooking oil to treat asthma.

With topical application modes, a handful of plant material is crushed or powdered and hand-applied for the treatment of skin related ailments. For example, swelled legs are treated by using 3-5 litre decoction of Adenia glauca by gently massaging legs. For bathing 3 to 5 litres of decoction is used to treat certain diseases. For ear related problems, one or two drops of the remedy are applied to the affected ear canal. Another dosage that was encountered is smoking, where a small amount is rolled in newspaper and smoked twice a day.

\section{Conservation status}

Of all documented plant species in the study area, $82 \%(n=29)$ appear in the South African National Biodiversity Institute's National Red Data List category as least concerned (LC) plant species. However, 8.5\% namely Elaeodendron tranvaalense, Drimia sanguine and D. pallidiflora are near threatened (NT). Hypoxis hemerocallidea is the only documented plant classified as declining (DC), and Drimia elata as Data Deficient Taxonomically Problematic (DDT). Monadenium lugardiae appear under the red data list as Not Evaluated (NE). No plant species are found under the highly important categories such as Critically Rare (CR), Critically Endangered (CR) (EN) and Regionally Extinct (RE).

This study found that the medicinal use is dominated by plants harvested from communal wild areas $(83.3 \%)$, as opposed to using cultivated plants $(16.2 \%)$ from home gardens. This dominance of using wild plants is supplemented by traditional healer's view that $69 \%$ of plants used are still commonly found, with $16.7 \%$ of spe- 
cies still viewed as abundantly distributed. Only $14.3 \%$ of plant species are viewed as rare.

\section{DISCUSSION}

\section{Species diversity}

The large floristic diversity of medicinal plants documented in the Mogalakwena Municipality does come as a surprise, seeing that previous records from Semenya (2012) only indicated 5 species being used in this area. Thus this study greatly expands on our understanding of the range of species being employed. The presence of such a large number of plant species and their associated ethno-medicinal knowledge indicates that the study area has a very high diversity of medicinal plants, and that indigenous knowledge of traditional health practitioners in this area compare favourably with findings of Semenya (2012) for the Limpopo Province as a whole, Tshisikhawe (2002) for the Venda area of the Limpopo Province, and De Wet et al. (2012) for the northern Maputaland, KwaZulu-Natal Province (South Africa). The fact that a number of species from this study is also commonly used in other parts of the province (Semenya \& Maroyi, 2013) and even in countries neighbouring South Africa such as Zimbabwe (Maroyi, 2013) is potentially a cultural indication of acceptance of efficacy.

The predominance of the Asteraceae and Fabaceae families in our study is consistent with finding obtained by Semenya et al. (2013a) at the Matebel-Village, located in the same Local Municipality. The prevalence of the Hyacinthaceae comes as no surprise as this family contains numerous species that are used throughout South Africa for their exceptional medicinal properties (Louw et al., 2002).

\section{Plant parts used}

Although medicinal properties of a species vary depending on part of the plant used, harvesting regimes, as well as geographical location and environmental conditions (Fennell et al., 2004), the high use of bark and roots as material can be attributed to their universally perceived high value as medicine irrespective of the above-mentioned influences in the study area. This finding is in line with those of Moeng and Potgieter (2011) and Semenya (2012) for the Limpopo Province. These plant parts are also favoured because they have long shelf-life when dried-stored (Street et al., 2008). Nevertheless, Semenya et al. (2013b) cautioned on the use of roots and stem as harvesting them have an extremely detrimental effect on the survival of individual plants. Williams et al. (2000) noted that when underground parts and stem-bark are mostly used, this will always results in plant mortality. In this regard, Shackleton et al. (2007) noted that harvesting bark, for example, opens wounds and exposes the plant to numerous pathogens that could ultimately lead to stem deterioration. In contrast to plant parts those are highly used. Fruit is rarely used as plant part for treatment of ailments (figure 3). The low use of fruit can be due to seasonal availability. The high frequency use of bark and roots is because these plant parts are always available throughout the year.

Numerous alternative methods of harvesting have been advocated. These include, amongst other, the utilization of leaves as alternatives (Moeng, 2010), harvesting material from different geographical locations (Semenya, 2012), and preventing ring-barking of woody species (Shackleton et al., 2007; van Wyk et al., 2009). The above-mentioned techniques will allow for a speedy recovery of individual plants and localised populations of a species. Thus, proper harvesting methods are deemed of vital importance to ensure long term species survival.

\section{Ailments treated}

The prevalence of various infections in the study area could results from various factors such as socio-economic status and environmental conditions. According to Norman et al. (2007) socio-economic status poses simultaneous risk for ill health related to industrialisation and underdevelopment. Respiratory infections in industrialised area are induced by air pollutants from various sources of contaminants such as factories, mining activities, and other sources of air pollution (Nriagu et al., 1999). In contrast, respiratory infections in underdeveloped can be ascribed to smoke inhalation from cooking fires as well as dust from gravel roads and this is consequence of inadequate supply of services such as electricity, tar-roads, water and sanitation (Röllin 
et al., 2004: Norman et al., 2007).

Mayosi et al. (2009) reported a shift of health related problems that are accompanied by the rise of non-communicable and prevalence of infectious diseases to poor rural communities. Demographic changes and low socioeconomic status are reported to increase non-communicable disease in low income people (Puoane et al. 2005). Prevalence of general diseases such as hypertension, blood impurity, and kidney and leaver failure could results from varying demographic changes (Hornbrook and Goodman, 1996). Gastro-intestinal infections such cholera and diarrhoea are widespread to areas that lack clean water and with poor sanitation. It should be noted that frequency of treated ailments does not necessarily reflect its prevalence, perhaps the knowledge and number of available medicinal plants used to treat such infections.

The traditional medicine employed by Bapedi healers covers a range of different ailments. Eleven categories are assigned according to most related ailments. This covers antidote (Snake bite and food poison), dermatological (Complexion, external sore, skin rush, swollen leg and wounds), Gastro intestinal system (Diarrhoea, dysentery, internal sore, stomach-ache, indigestion, and vomit), General diseases (Immunization, fever, hypertension, Blood cleaning, leaver and kidney failure), Gynaecological (Womb cleaner, Infertility, uncontrolled menstruation), musculoskeletal system (Arthritis and muscle pains), oral infections (Toothache and dental worms), respiratory infections (Asthma, cold and flu, chough, nasal block, and sore throat), STDs (gonorrhoea and HIV/AIDS), fainting, sore eyes and earaches.

Various plants can be used to treat common ailment. A phenomenon observed by several studies in South Africa and elsewhere (Mathabe et al., 2006; York et al., 2011; Semenya and Potgieter, 2012; Maroyi, 2013; Muthu et al., 2006). Omoruyi et al. (2012) found five different plant species used for treatment of diarrhoea in Eastern Cape of South Africa. In our study, seven plants (Dicoma anomala subsp gerraddi, Ozoroa sphaerocarpa, Artemisia afra, Terminalia sericea, Schotia brachypetala, Geigeria aspera, Dicoma anomala subsp anomala) are used for treatment of cough (Table 1). The use of Artemisia afra and Geigeria aspera for treatment of cough is also reported in Limpopo province for TB, ailment related to cough (Semenya and Maroyi, 2013). Leaves decoction of $A$. afra is administered orally to ease cough, it is believed that $A$. afra clear the respiratory and bronchial passages (Viljoen, 2007).

Six plants species are used for blood cleaning and most of them are from the family Fabaceae (Albizia versicolor, Elephantorrhiza elephantina and Peltophorum africanum), followed by two plant species from Hyacinthaceae family (Drimia elata and Eucomis pallidiflora). The use of Drimia elata and Elephantorrhiza elephantina for blood cleaning is consistence with other ethnomedicinal studies in Limpopo Province (Semenya et al., 2013). Other plants used for blood cleaning include Hypoxis hemerocallideaa and Elaedendron transvaalense (Table 1). A Gastro intestinal ailment such as internal sore is treated using five plant species. Plants used to treat internal sores include Aloe marlothii, Hypoxis hemerocallidea, Geigeria aspera and Ziziphus mucronata.

It is also important to note that some of the plants are used for treatment of more than two ailments (Maroyi, 2013). These finding are in agreement with this study which shows that of all reported plants species in the study area 35\% (14) are used to treat two ailments, $7.5 \%$ (3) treat three different ailments whereas $12.5 \%$ (5) can treat more than four ailments (Figure 4). For example, Boscia albitrunca is used to treat epilepsy and snake bites. Solanum panduriforme is documented for dental worms, external sore and wounds.

Hypoxis hemerocallidea is used to treat six different ailments (Table 1 and figure 4). Treatment of diarrhea and dysentery with $\mathrm{H}$. hemerocallid$e a$ is validated through ethnobotanical studies by other ethnic groups and through phytochemical analysis. Bisi-Johnson et al. (2010) reported the use of $\mathrm{H}$. hemerocallidea for diarrhea by Xhosa people in Eastern Cape of South Africa. The antidiarrhoeal activity of $H$. hemerocallidea was validated through phytochemical analysis (Ojewole et. al., 2009). Other ailments treated by $H$. hemerocallidea include hypertension, internal sores, stomach-ache, Kidneys problems and blood cleaner. The alternative use of medicinal plant is of benefits as it provides plant of choice to treat ailments. This also reflects rich ethnome- 
dicinal knowledge employed by Bapedi traditional healer.

\section{Preparation of remedies}

Tradition healers normally prefer crude extract for medicinal preparation (Drewes et al., 2006). Various preparation methods, such as boiling, pounding and maceration are used by Bapedi traditional health practitioners. These are the most common methods of medicinal preparation used in South Africa (De Wet et al., 2012) and other African countries (Njoroge and Bussmann, 2009). Seventy three percent of the plant material in this study was boiled in water. De Wet et al. (2012) and Njoroge and Bussmann (2009) also noted the preference for boiling material. This might be due to the simplicity of preparation.

About $87 \%$ of remedies was prepared from only one species, $10 \%$ through a mixture of two different species, and in 3\% of cases material from three plant species were combined to prepare a remedy. The practice of combing different species to treat ailments is a fairly common practice throughout South Africa. De Wet et al. (2012) reported this for the Zulu lay people, Semenya (2012) noted it for the Bapedi, and Tshisikhawe (2002) for the Venda area. Semenya (2012) further noted that Bapedi healers indicated that they combine species to re-enforce the medicines and increase its efficacy. This observation is in agreement with the study by Mabogo (1990) for Vha-Venda traditional health practitioners. It is interesting to note that pharmacological studies support this claim (Chow et al., 2003). This was further scientifically validated by Erasmus (2014), who showed that in some cases a combination mimics the broad spectrum antibiotics used in modern medicine.

The preference of a single species by Bapedi healers in the preparation of extracts might be linked to their local availability. In the Southern Tigray, Northern Ethiopia, Giday and Gobana (2010) postulated that the wide utilization of a single plant species in the preparation of indigenous remedies by healers is ascribed to the differences in the socio-cultural landscapes, indigenous knowledge on synergetic effect of different medicinal plants and vegetation types. Saikia et al. (2006) reported that use of a single species in the preparation of an extract could be of great interest for the development of novel drugs as the exploration of therapeutic activity-bearing ingredients may be easier. However, according to Semenya et al. (2013b), the use of a single species by Bapedi healers in the preparation of extracts has both advantages and disadvantages from a conservation point of view. As noted earlier when used to treat an ailment it reduces harvesting pressure of being multi-used, likewise the opposite increases harvesting, thereby posing a threat.

\section{Mode of administration}

A variety of methods are employed for administration of herbal medicine by Bapedi traditional health practitioners. However, findings from this study illustrate that oral self-administration $(71.7 \%)$ was the method of choice. Studies such as Kambizi and Afolayan (2001) and Chigora et al. (2007) also noted that most medicines used in the treatment of various ailments are prescribed orally. The preference of this method by Bapedi traditional health practitioners might be due to the fact that medication in liquid form is already dissolved, so it can readily be absorbed by the human body (Semenya et al., 2013a).

\section{Dosage}

\section{Conservation status}

Although $82 \%$ of plant species documented in this study are categorised as Least Concern in the Red Data List of South Africa (SANBI 2012), species such as Elaeodendron transvaalense and Drimia sanguine are highly exploited for their perceived medicinal properties. These plants are declining in local and regional level respectively (Williams et al., 2013). This is in line with finding from this study, which noted that traditional health practitioners perceived these species as rare. Numerous studies such as Moeng and Potgieter (2011), Mathibela (2012) and Semenya et al. (2013b) alluded to the fact that healers in the Limpopo Province are unaware of Red Data-listed species, or species of special concern, or even species that are protected via various national and provincial legislations. This calls for urgent awareness programmes on the conservation status of medicinally used plants, as this could assist with natural resource management. 


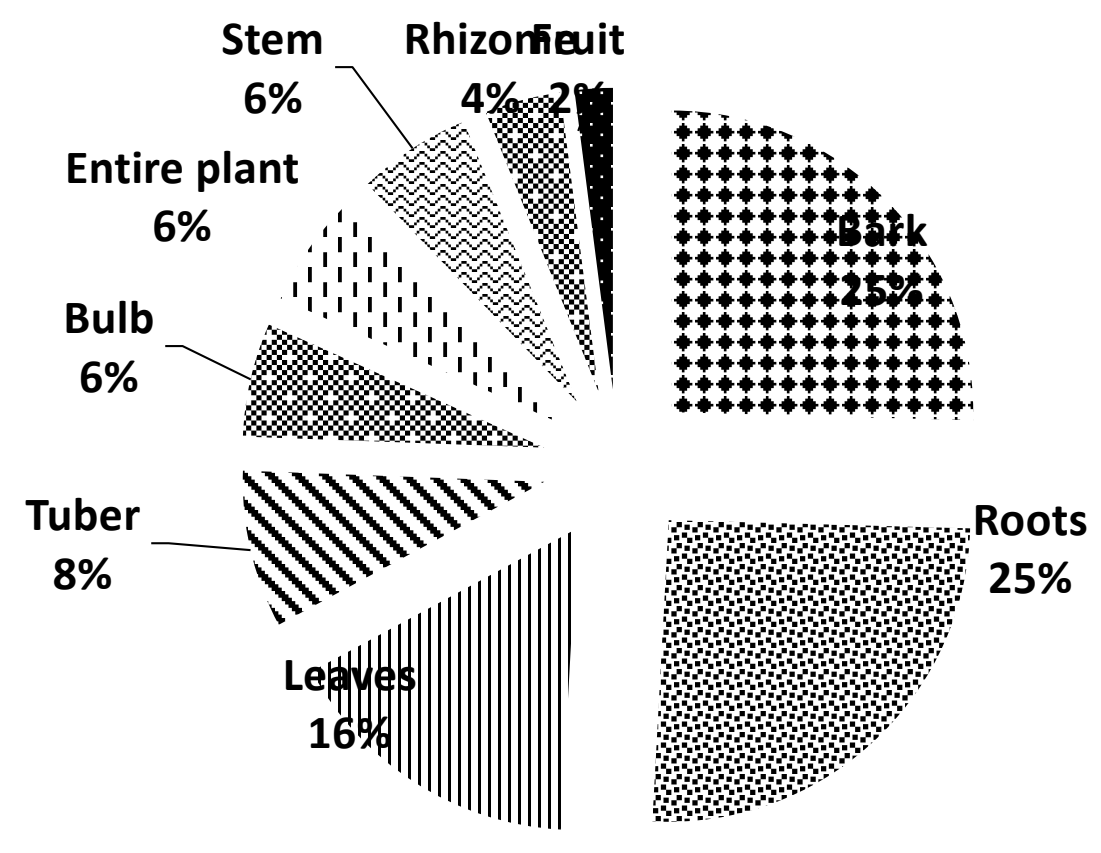

Figure 3. Plant parts used for medicinal preparation.

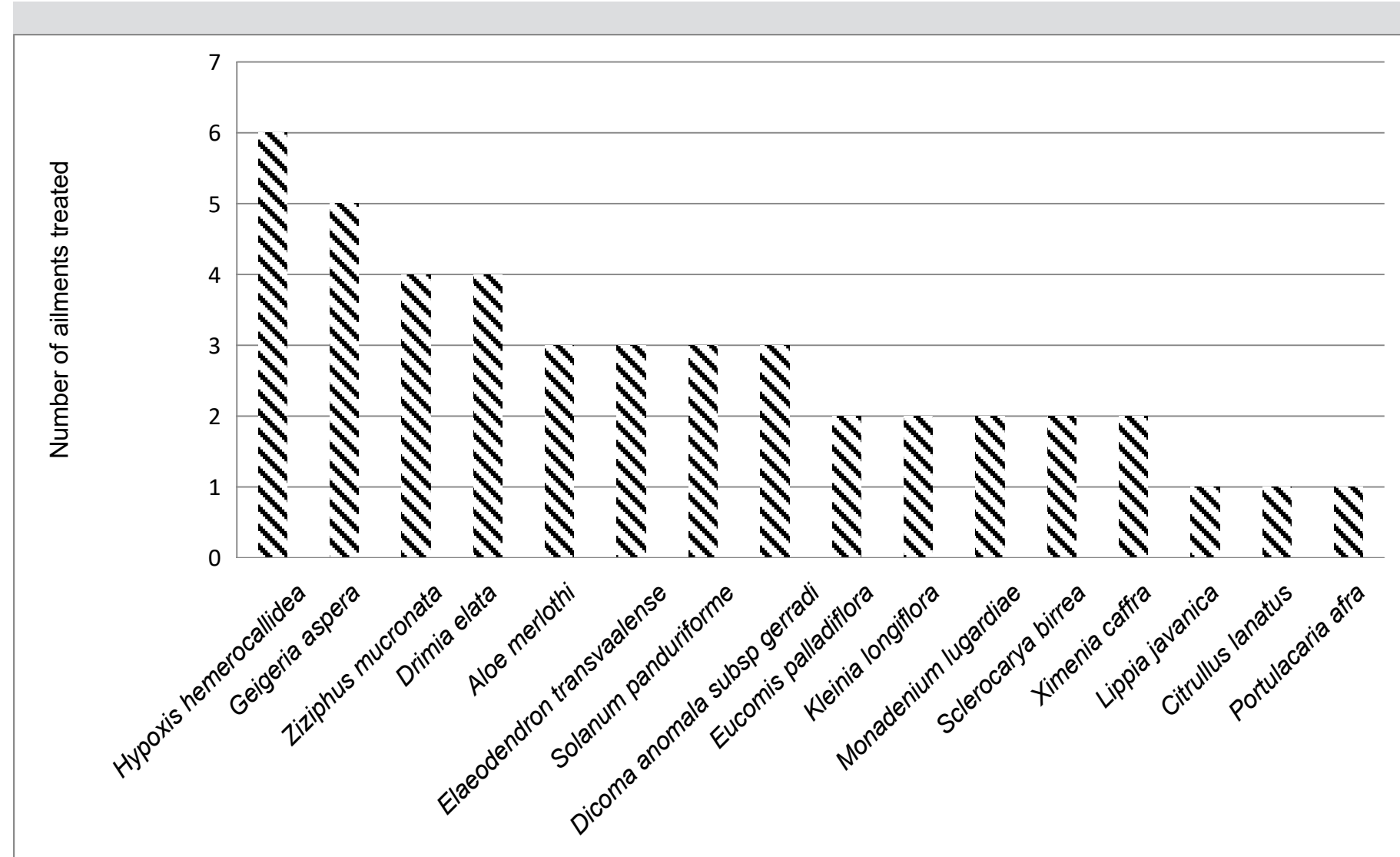

Figure 4: Number of ailments treated by documented plant species. 


\section{CONCLUSIONS}

Traditional medicine plays an important role in primary health care of Mogalakwena residents. The large number of species employed to treat a variety of ailment clearly reflects the rich diversity of treatment protocols used by Bapedi healers. Further studies to determine the efficacy of some of the recorded species against the reported ailment is strongly recommended.

\section{ACKNOWLEDGEMENTS}

All traditional health practitioners who participated in this study are highly acknowledged for sharing their knowledge. The University of Limpopo is acknowledged for financial support.

\section{REFERENCES}

Akaydin, G., Simşek, I., Arituluk, Z.C. \& Yeşilada, E. 2013. An ethnobotanical survey in selected towns of the Mediterranean subregion (Turkey). Turkish Journal of Biology 37: 230-247.

Bisi-Johnson, M.A., Obi, C.L., Kambizi, L. \& Nkomo, M. 2010. A survey of indigenous herbal diarrhoeal remedies of OR Tambo district, Eastern Cape Province, South Africa. African Journal of Biotechnology, 9: 1245-1254.

Chigora, P., Masocha, R. \& Mutenheri, F. 2007. The role of indigenous medicinal knowledge (IMK) in the treatment of ailments in rural Zimbabwe: The case of of Mutirikwi Communal Lands. Journal of Sustainable Development in Africa 9: 26-43.

Chow, K.U., Nowak, D., Boehrer, S., Ruthardt, M., Knau, A., Hoelzer, D., Mitrou, P.S. \& Weidmann, E. 2003. Synergistic effects of chemotherapeutic drugs in lymphoma cells are associated with down-regulation of inhibitor of apoptosis proteins (IAPs), prostate-apoptosis-response-gene 4 (Par-4), death-associated protein (Daxx) and with enforced caspase activation. Biochemical Pharmacology 66: 711-724.

Dahlberg, A.C. \& Trygger, S.B. 2009. Indigenous medicine and primary health care: The importance of lay knowledge and use of medicinal plants in rural South Africa. Human Ecology 37: 79-94.

De Wet, H., Nzama, V.N. \& Van Vuuren, S.F. 2012. Medicinal plants used for the treatment of sexually transmitted infections by lay people in northern Maputaland, KwaZulu-Natal Province, South Africa. South African Journal of Botany, 78:12-20.

Drewes, S., Horn, M. \& Khan, F. 2006. The chemistry and pharmacology of medicinal plants. In: Diederichs, N. (ed.), Commercialising Medicinal Plants
- A Southern African Guide, pp. 87-96. Sun Press, Stellenbosch.

Dladla, C.N. 2013. Factors contributing to non-compliance to pulmonary tuberculosis treatment among patients in Waterberg District Limpopo Province. M.Sc. Dissertation. University of South Africa.

Driver, A., Sink, K.J., Nel, J.L., Holness, S., Van Niekerk, L., Daniels, F., Majiedt, P.A., Jonas, Z. \& Maze, K., 2012. National Biodiversity Assessment 2011: An assessment of South Africa's biodiversity and ecosystems. Synthesis Report. South African National Biodiversity Institute and Department of Environmental Affairs, Pretoria.

Erasmus, L.J.C. 2014. An ethnopharmacological assessment of extract preparation, the identification of crude compounds, and in vitro antimicrobial efficacy of phytomedicine employed by the Bapedi in the Limpopo Province, South Africa. PhD Thesis, University of Limpopo, Mankweng.

Fennell, C.W., Light, M.E., Sparg, S.G., Stafford, G.I. \& Van Staden, J. 2004. Assessing African medicinal plants for efficacy and safety: Agricultural and storage practices. Journal of Ethnopharmacology 95: 113-121.

Giday, M. \& Gobana, A. 2010. An ethnobotanical survey on plants of veterinary importance in two woredas of Southern Tigray, Northern Ethiopia: SINET. Ethiopian Journal of Science 26: 123-136.

Hornbrook, M.C. \& Goodman, M.J. 1996. Chronic disease, functional health status, and demographics: a multi-dimensional approach to risk adjustment. Health services research, 31: 283.

Iwu, M.M. 2014. Handbook of African Medicinal Plants. $2^{\text {nd }}$ Edition. CRC Press, Boca Raton.

Kambizi, L. \& Afolayan, A.J. 2001. An ethnobotanical study of plants used for the treatment of sexually transmitted diseases (Njovhera) in Guruve District, Zimbabwe. Journal of Ethnopharmacology 77: 5-9.

Lewu, F.B. \& Afolayan, A.J. 2009. Ethnomedicine in South Africa: The role of weedy species. African Journal of Biotechnology 8: 929-934.

Louw, C.A.M., Regnier, T.J.C. \& Korsten, L. 2002. Medicinal bulbous plants of South Africa and their traditional relevance in the control of infectious diseases. Journal of Ethnopharmacology 82: 147-154.

Mabogo, D.E.N. 1990. The ethnobotany of the Vha-Venda. M.Sc. Dissertation. University of Pretoria, Pretoria.

Maroyi, A. 2011. An ethnobotanical survey of medicinal plants used by the people in Nhema communal area, Zimbabwe. Journal of Ethnopharmacology 136: 
347-354.

Maroyi, A. 2013. Traditional use of medicinal plants in south-central Zimbabwe: review and perspectives. Journal of ethnobiology and ethnomedicine, 9: 31.

Mathabe, M.C., Nikolova, R.V., Lall, N. \& Nyazema, N.Z. 2006. Antibacterial activities of medicinal plants used for the treatment of diarrhoea in Limpopo Province, South Africa. Journal of Ethnopharmacology 105: 286-293.

Mathibela, K.M. 2012. Medicinal plants and their conservation status as used by traditional healers around the Blouberg Mountain, Limpopo Province. MSc Dissertation. University of Limpopo, Mankweng.

Muthu, C., Ayyanar, M., Raja, N. \& Ignacimuthu, S. 2006. Journal of Ethnobiology and Ethnomedicine. Journal of Ethnobiology and Ethnomedicine, 2: 43.

Norman, R., Cairncross, E., Witi, J., Bradshaw, D., \& Collaboration, S. A. C. R. A. 2007. Estimating the burden of disease attributable to urban outdoor air pollution in South Africa in 2000. South African Medical Journal, 97: 782-790.

Mannino, D.M. \& Buist, A. S. 2007. Global burden of COPD: risk factors, prevalence, and future trends. The Lancet, 370: 765-773.

Mayosi, B.M., Flisher, A.J., Lalloo, U.G., Sitas, F., Tollman, S.M. \& Bradshaw, D. 2009. The burden of non-communicable diseases in South Africa. The Lancet 374: 934-947.

McGaw, L., Jäger, A., Grace, O., Fennell, C. \& van Staden, J. 2005. Medicinal Plants. In: van Niekerk, A. (ed.), Ethics in Agriculture-An African Perspective, pp. 67-83. Springer, Dordrecht, Netherlands.

Moeng, T.E. 2010. An investigation into the trade of medicinal plants by Muthi shops and street vendors in the Limpopo Province, South Africa. M.Sc. Dissertation. University of Limpopo, Mankweng.

Moeng, E.T. \& Potgieter, M.J. 2011. The trade of medicinal plants by muthi shops and street vendors in the Limpopo Province, South Africa. Journal of Medicinal Plants Research 5: 558-564.

Nriagu, J., Robins, T., Gary, L., Liggans, G., Davila, R., Supuwood, K. \& Naidoo, R. 1999. Prevalence of asthma and respiratory symptoms in south-central Durban, South Africa. European journal of epidemiology, 15: 747-755

Njoroge, G.N. \& Bussmann, R.W. 2009. Ethnotherapeutic management of sexually transmitted diseases (STDs) and reproductive health conditions in Central Province of Kenya. Indian Journal of Traditional Knowledge, 8: 255-261.
Ojewole, J.A., Awe, E.O. \& Nyinawumuntu, A. 2009. Antidiarrhoeal activity of Hypoxis hemerocallidea Fisch. \& CA Mey.(Hypoxidaceae) Corm ('African potato') aqueous extract in rodents. Phytotherapy Research, 23: 965-971.

Puoane, T., Tsolekile, L., Sanders, D. \& Parker, W. 2008. Chronic non-communicable diseases: primary health care: programme areas. South African Health Review 5: 73-87.

Röllin, H.B., Mathee, A., Bruce, N., Levin, J. \& Von Schirnding, Y.E.R. 2004. Comparison of indoor air quality in electrified and un $\square$ electrified dwellings in rural South African villages. Indoor Air, 14: 208-216.

Saikia, A.P., Ryakala, V.K., Sharma, P., Goswami P. \& Bora, U. 2006. Ethnobotany of medicinal plants used by Assamese people for various skin ailments and cosmetics. Journal of Ethnopharmacology 106:149-157.

Seid, M.A. \& Aydagnehum, S.G. 2013. Medicinal plants biodiversity and local healthcare management system in Chencha District; Gamo Gofa, Ethiopia. Journal of Pharmacognosy and Phytochemistry 2: 284-293.

Semenya, S.S. 2012. Bapedi phytomedicine and their use in the treatment of sexually transmitted diseases in Limpopo Province, South Africa. MSc Dissertation. University of Limpopo, Mankweng.

Semenya, S.S. \& Maroyi, A. 2013. Medicinal plants used for the treatment of tuberculosis by Bapedi traditional healers in three districts of the Limpopo Province, South Africa. African Journal of Traditional, Complementary and Alternative Medicines 10: 316323.

Semenya, S.S. \& Potgieter, M.J. 2013a. Ethnobotanical survey of medicinal plants used by bapedi traditional healers to treat erectile dysfunction in the Limpopo Province, South Africa. Journal of Medicinal Plants Research, 7: 349-357.

Semenya, S.S., Potgieter, M.J. \& Erasmus L.J.C. 2013b. Bapedi phytomedicine and their use in the treatment of sexually transmitted infections in Limpopo Province, South Africa. African Journal of Pharmacy and Pharmacology 7: 250-262

Semenya, S.S., Potgieter, M.J. \& Tshisikhawe, M.P. 2013c. Use, conservation and present availability status of ethnomedicinal plants of Matebele-village in the Limpopo province, South Africa. African Journal of Biotechnology 12: 2392-2405.

Shackleton, C.M., Shackleton, S.E., Buiten, E. \& Bird, N. 2007. The importance of dry woodlands and forests in rural livelihoods and poverty alleviation in South Africa. Forest Policy and Economics 9: 558577. 
South Africa National Biodiversity Institute (SANBI). 2012. Online checklist of Southern African plant species. Http://posa.sanbi.org. Accessed 17 November 2014.

\section{StatsSA. 2012. Census 2012.}

Street, R. A., Stirk, W. A. \& Van Staden, J. 2008. South African traditional medicinal plant trade-challenges in regulating quality, safety and efficacy. Journal of Ethnopharmacology, 119: 705-710.

Street, R.A. \& Prinsloo, G. 2012. Commercially important medicinal plants of South Africa: A review. Journal of Chemistry 2013: 1-16.

Truter, I. 2007. African traditional healers: Cultural and religious beliefs intertwined in a holistic way. South African Pharmaceutical Journal 74: 56-60.

Tshisikhawe, N.P. 2002. Trade of indigenous medicinal plants in the Northern Province, Venda Region: Their ethnobotanical importance and sustainable use. M.Sc. Dissertation. University of Venda, Thohoyandou.

Van Vuuren, S.F. 2008. Antimicrobial activity of South African medicinal plants. Journal of Ethnopharmacology, 119: 462-472.

Van Wyk, A.E. \& Smith G. 2001. Regions of Floristic Endemism in Southern Africa: A Review with Emphasis on Succulents. Umdaus Press, Hatfield, Pretoria.

Van Wyk, B.E. 2008. A broad review of commercially important southern African medicinal plants. Journal of Ethnopharmacology 119: 342-355.

Van Wyk, B.E., Van Oudtshoorn, B. \& Gericke, N. 2009. Medicinal Plants of South Africa. Second edition. Briza Publications, Pretoria.

Viljoen, A. 2007. Indigenous South African Medicinal Plants: part 2: Artemisia afra (wild wormwood): medicinal plants. SA Pharmaceutical Journal, 74: 58-58.

Weitz, F.M. \& Thring, T.S.A. 2005. Medicinal plant use in the Bredasdorp/Elim region of the Southern Overberg in the Western Cape Province of South Africa. Journal of Ethnopharmacology 103: 261-275.

World Health Organization (WHO). 2002. Traditional medicine strategy 2002-2005. World Health Organization, Geneva.

Williams, V.L., Balkwill, K. \& Witkowski, E.T. 2000. Unraveling the commercial market for medicinal plants and plant parts on the Witwatersrand, South Africa. Economic Botany 54: 310-327.

Williams, V.L., Victor, J.E. \& Crouch, N.R. 2013. Red listed medicinal plants of South Africa: Status, trends, and assessment challenges. South African Journal of Botany 86: 23-35.
ZHANG, X. 2004. Traditional Medicine: Its Importance and Protection. The role of Traditional Knowledge in Healthcare and Agriculture. In: Twarog $S$ and Kapoor, P. (eds.). Protecting and Promoting Traditional Knowledge: Systems, National Experiences and International Dimensions. United Nations Conference on Trade and Development. New York and Geneva.

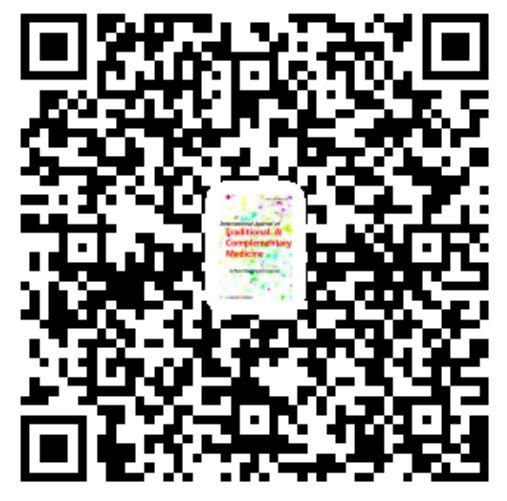




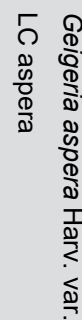

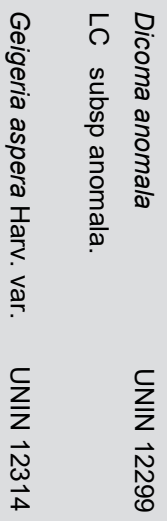

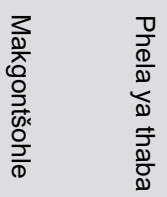

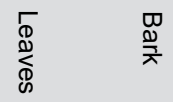

$\stackrel{M}{E}$

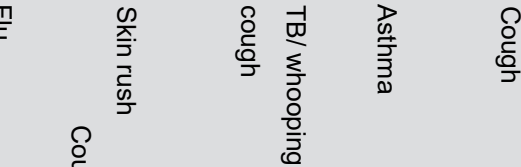

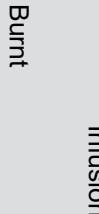

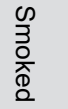

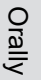

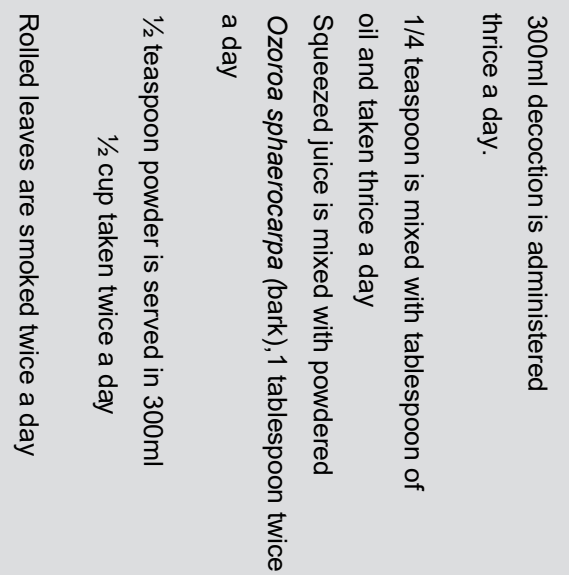

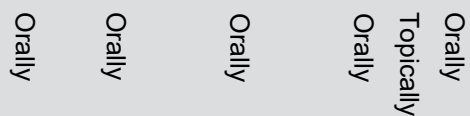

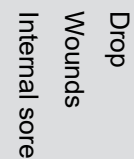

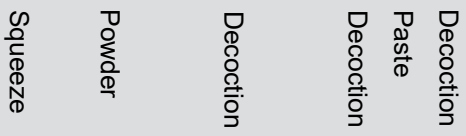<smiles>[CH]C</smiles>

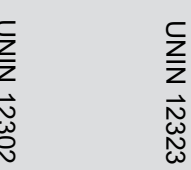

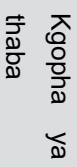

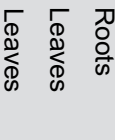

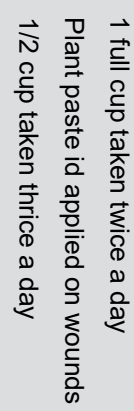

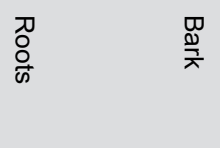

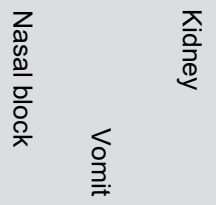

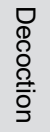<smiles>C1CCC2(CC1)CCCC2</smiles>

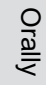

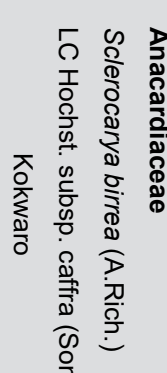

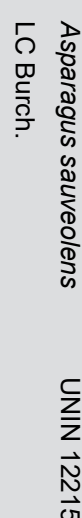

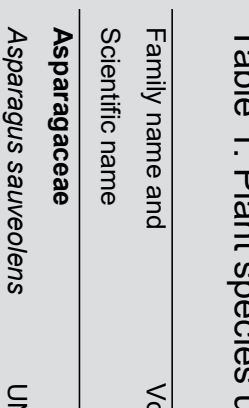

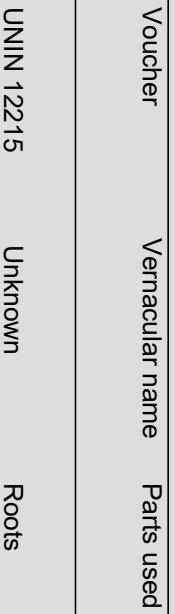

क

क

家

$\stackrel{0}{\stackrel{2}{\leftrightarrows}}$

ฏ.

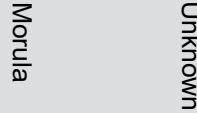

章.

气ิ

定

ํํำ

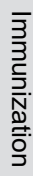

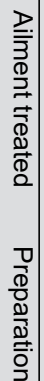

으

을

을.

$\frac{1}{0}$
के
$\frac{3}{7}$

蛋.

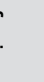

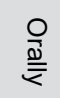

$\stackrel{\stackrel{ㅇ}{\stackrel{P}{*}}}{=}$

3
$\frac{2}{0}$
0
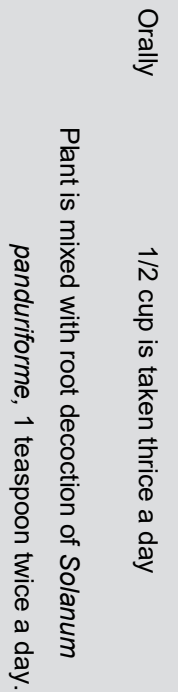


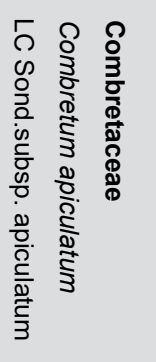

$\complement$
$\Sigma$
$\stackrel{N}{N}$

을

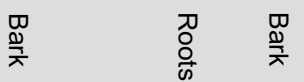

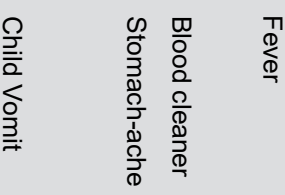

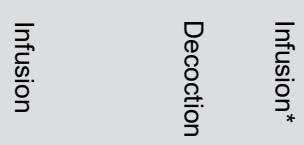

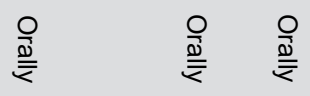

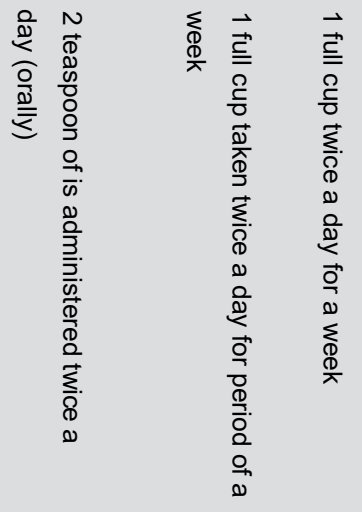

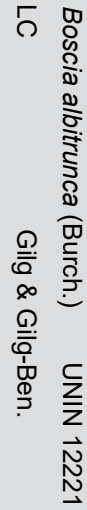

$\stackrel{3}{\stackrel{3}{\circ}}$<smiles>[CH]C=[Co]</smiles>

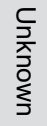

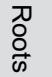<smiles>CCCC</smiles><smiles>[O-][B][Ca]</smiles>

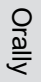

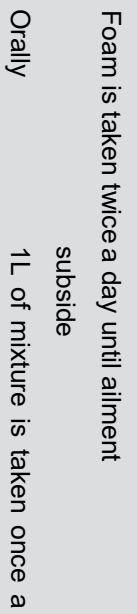

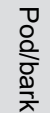

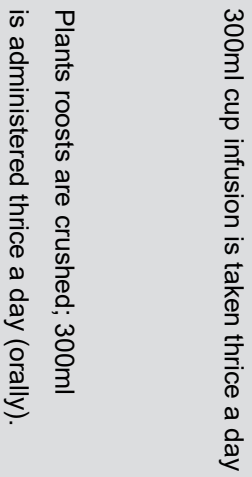

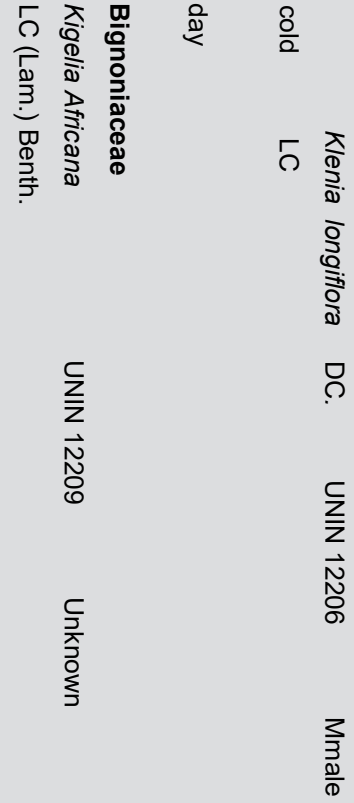

$\frac{\mathscr{C}}{\mathrm{D}}$

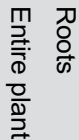

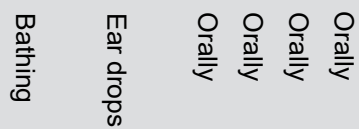

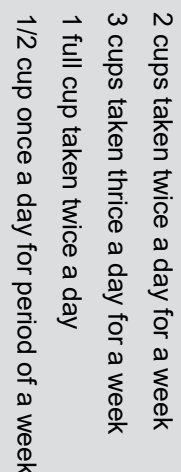



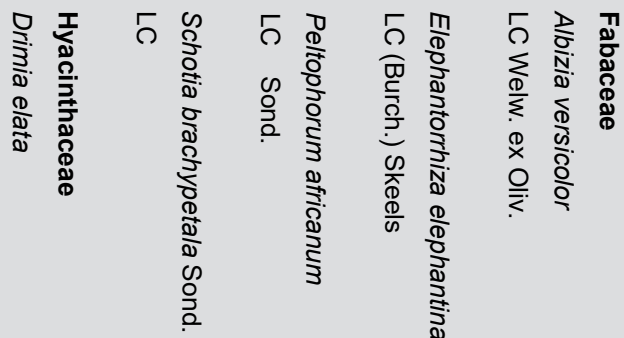

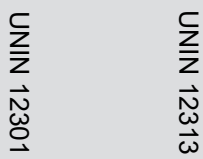

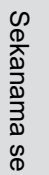

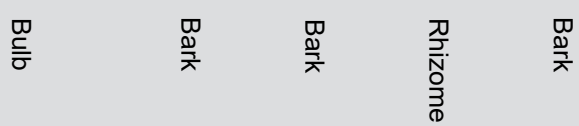

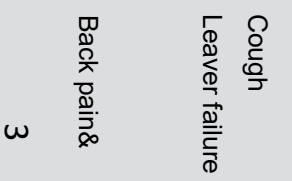

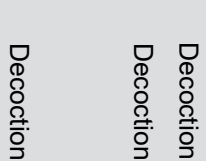

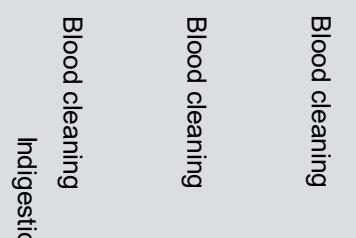
के

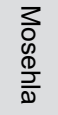
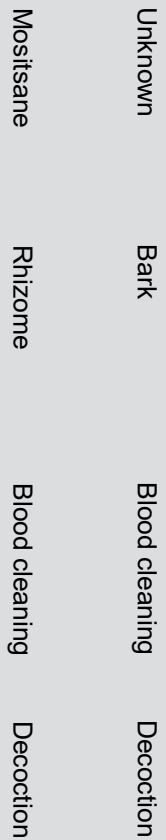

蛋.

일 道道
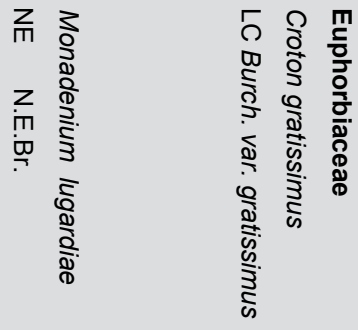

$\complement$
Z
N
V

3
을
응
$\frac{8}{0}$

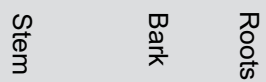

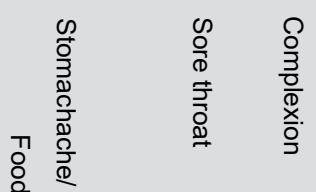

을.

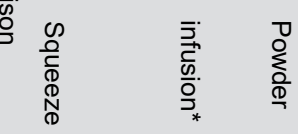

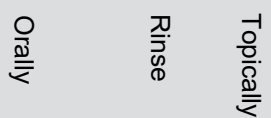

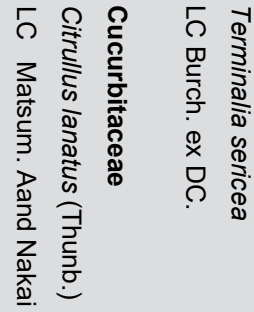

$\begin{array}{ll}\sqsubseteq & c \\ & \bar{Z} \\ \vec{U} & \vec{N} \\ \vec{U} & \vec{N}\end{array}$

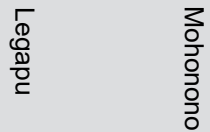<smiles>[CH][CH]</smiles>

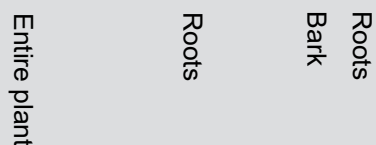

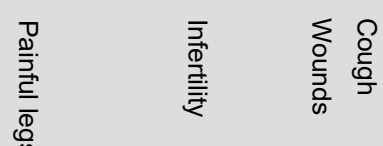

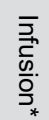

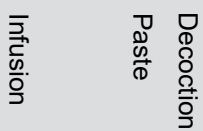

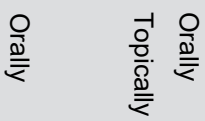

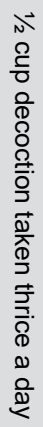
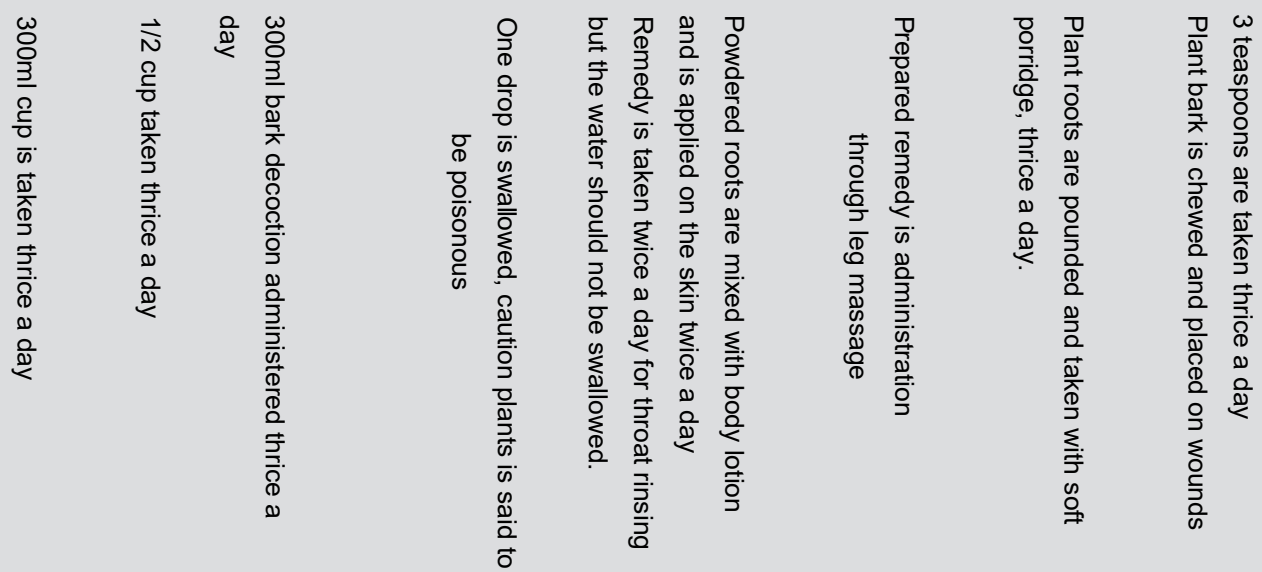
Maema et al., IJTCM, 2016; Vol. 1(4): 0028-0044
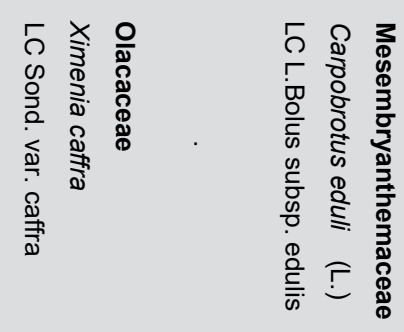

$\stackrel{C}{Z}$
$\vec{N}$
$\stackrel{N}{O}$

$\frac{c}{\sum}$

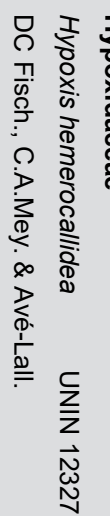

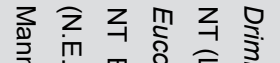

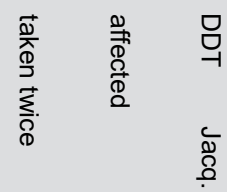

$\frac{3}{0}$
$\frac{0}{0 x}$
훙.

$\stackrel{?}{\frac{3}{2}}$

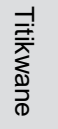

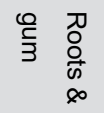

$\underset{\mathbb{D}}{\stackrel{\$}{\$}}$

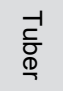

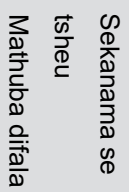

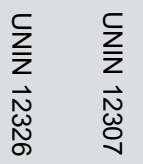

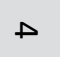

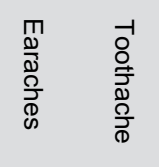

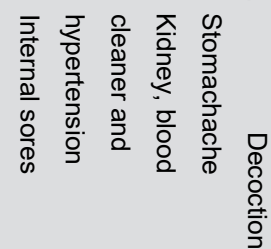

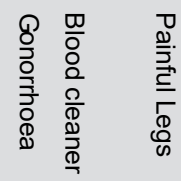

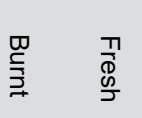

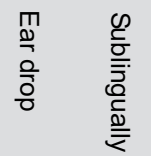

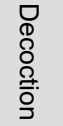

$\begin{array}{ll}\text { D } \\ \stackrel{D}{\bar{\sigma}} & \stackrel{D}{\sigma}\end{array}$

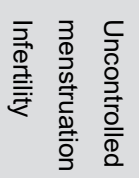

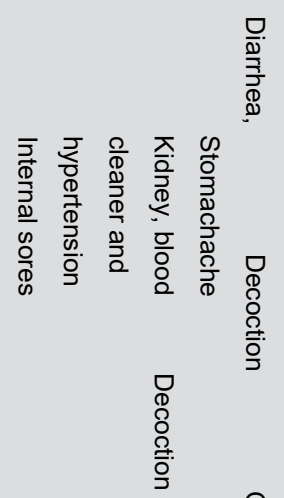

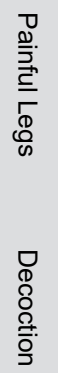

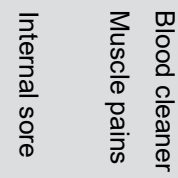

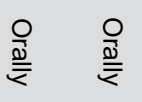

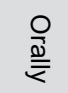

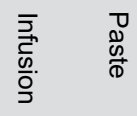
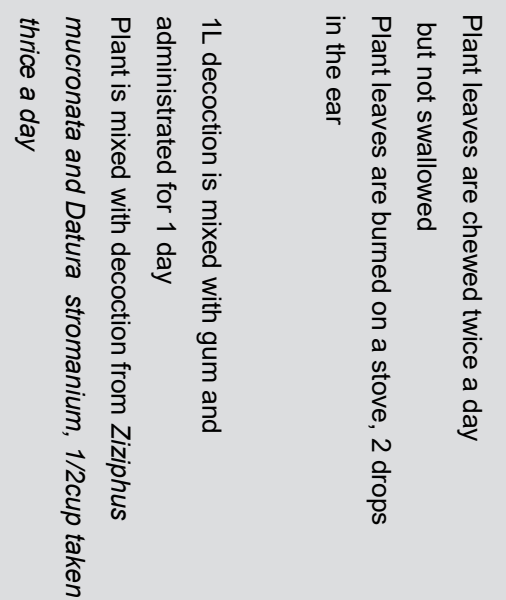

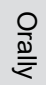

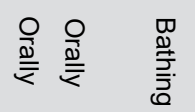
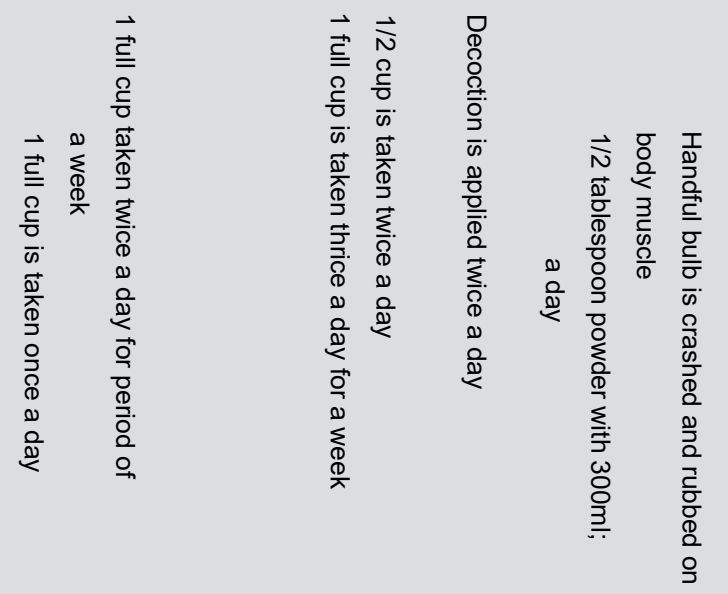


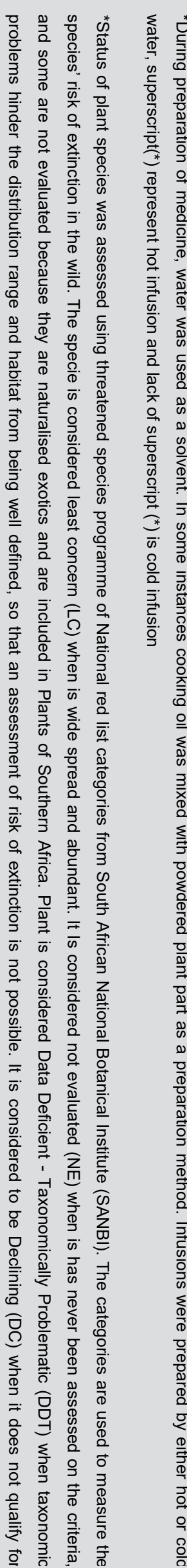

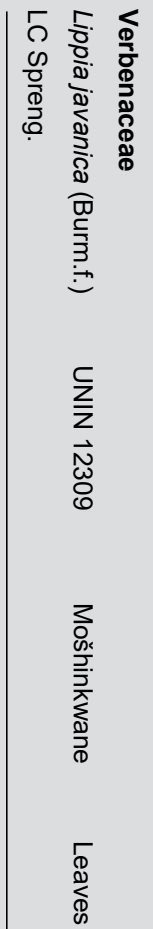

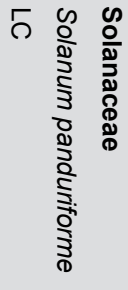

$\stackrel{\nwarrow}{z}$

$\frac{-1}{\frac{1}{0}}$

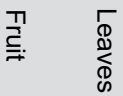

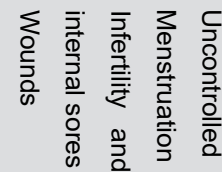

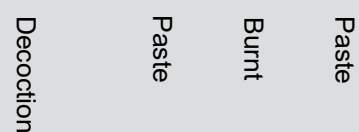

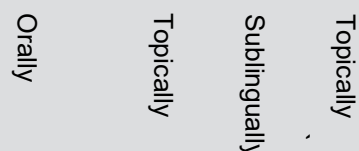

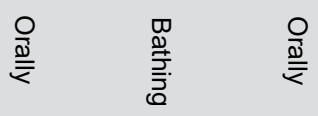
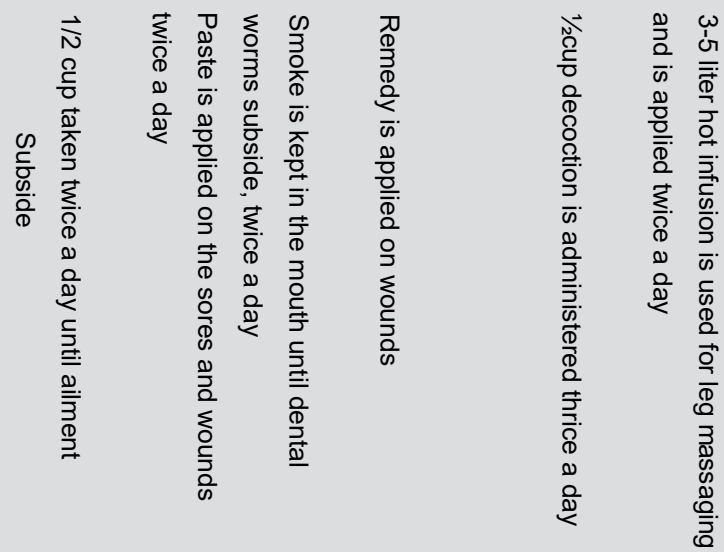

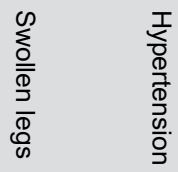

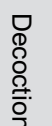

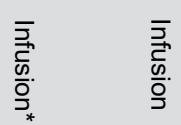

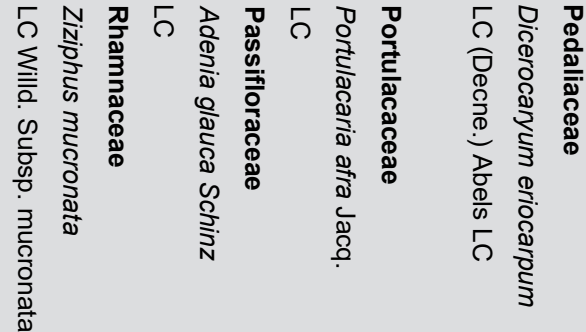

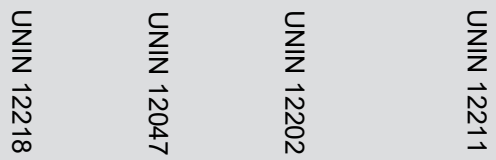

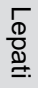

ग0
ळे

$\sum$
$\frac{1}{3}$
$\frac{0}{0}$
$\frac{0}{D}$
$\frac{0}{10}$
$\frac{0}{10}$

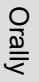

